\title{
PEMANFAATAN MATERI PERJANJIAN KERJA SAMA SEBAGAI MEDIA PEMBELAJARAN PKN UNTUK MENINGKATKAN HASIL BELAJAR PESERTA DIDIK HOMESCHOOLING
}

\author{
Ahmad Nasir Ari Bowo ${ }^{1}$, Intan Kusumawati² \\ ${ }^{1,2}$ Pendidikan Pancasila dan Kewarganegaraan, Universitas Cokroaminoto Yogyakarta \\ Jl. Perintis Kemerdekaan, Gambiran, Umbulharjo, Kota Yogyakarta 55161 \\ ${ }^{1}$ Email: ahmadnasir@ucy.ac.id \\ 2Email: intankusumawati1978@gmail.com
}

\begin{abstract}
ABSTRAK
Tahapan implementasi pemanfaatan materi perjanjian kerjasama sebagai media pembelajaran di bagi menjadi tiga tahap. Tahap pertama yaitu perencanaan, tutor membuat rencana pelaksanaan pembelajaran. Tahap kedua yaitu tahap pelaksanaan, meliputi identifikasi materi hubungan internasional melalui perjanjian kerja sama internasional, perundingan, perumusan naskah dan pengesahan sehingga disepakati isi piagam perjanjian kerja sama. Tahap ketiga yaitu evaluasi, untuk mengetahui hasil belajar melalui penilaian afektif, psikomotorik dan kognitif. Selanjutnya diperoleh dampak hasil pembelajaran.

Pemanfaatan materi perjanjian kerjasama sebagai media pembelajaran dapat meningkatkan hasil belajar peserta didik dalam pembelajaran PKN. Persentase rata-rata hasil belajar peserta didik sebelum dilakukan tindakan adalah 28\%. Selanjutnya setelah dilakukan tindakan pada siklus pertama meningkat menjadi $34 \%$. Sedangkan pada siklus kedua meningkat menjadi $38 \%$.
\end{abstract}

Kata Kunci: Materi, Perjanjian Kerja Sama, Media PKN, Hasil Belajar.

\section{ABSTRACT}

Stages of Implementation of the Cooperation Agreement Material as a Learning Media for Becoming Three People. The first stage is planning, tutors make plans to implement learning. The second stage is the implementation stage, containing material on international relations through international cooperation agreements, negotiations, the formulation of texts and endorsements so that the contents of the cooperation agreement are agreed. The third stage is evaluation, for learning the results of learning through affective, psychomotor and cognitive. Furthermore, learning outcomes are obtained.

Utilization of cooperation agreement material as a learning medium can improve student learning outcomes in PKN learning. The average percentage of student learning outcomes before action is $28 \%$. Furthermore, after the action in the first cycle increased to $34 \%$. Whereas in the second cycle increased to $38 \%$.

Keywords: Material, Cooperation Agreement, citizenship Media, Learning Outcomes.

\section{PENDAHULUAN}

Terdapat beberapa permasalahan selama proses pembelajaran PKN pada Satuan Pendidikan Kesetaraan Paket B kelas 9 semester genap tahun 2019 di Homeschooling Kota 
Yogyakarta. Permasalahan tersebut yaitu rendahnya hasil belajar peserta didik pada kompetensi dasar mendeskripsikan politik luar negeri dalam hubungan internasional di era global. Peserta didik belum bisa memahami secara mendalam materi tentang politik luar negeri dalam hubungan internasional di era global. Mereka masih kesulitan dalam mendeskripsikan konsep politik luar negeri dan gambaran umum dalam melaksanakan hubungan internasional di era global. Dengan demikian rata-rata hasil belajar peserta didik masih di bawah kriteria ketuntasan minimal dan berdampak pada rendahnya hasil belajar peserta didik.

Hasil wawancara dan diskusi saya dengan beberapa tutor yang mengajar pada kelas 9 Homeschooling Anak Pelangi Yogyakarta pada saat kegiatan belajar mengajar serta di saat rapat tutor dapat disimpulkan bahwa hasil belajar peserta didik masih rendah. Beberapa permasalahan pembelajaran PKN khususnya pada kompetensi dasar mendeskripsikan politik luar negeri dalam hubungan internasional di era global pada kelas 9 semester genap tahun 2019 di Homeschooling Anak Pelangi Kota Yogyakarta dapat disimpulkan antara lain peserta didik masih kesulitan dalam memahami materi, sehingga hasil belajar peserta didik masih rendah.

Pembelajaran inovatif diperlukan untuk meningkatkan hasil belajar. Salah satu pembelajaran inovatif yang dibuat mampu mengatasi permasalahan yang ada yaitu pemanfaatan materi perjanjian kerja sama sebagai media pembelajaran PKN. Dengan demikian judul yang saya buat dalam penelitian tindakan ini adalah pemanfaatan materi perjanjian kerja sama sebagai media pembelajaran PKN untuk meningkatkan hasil belajar peserta didik Homeschooling. Fokus dalam penerapan pembelajaran ini adalah pada kelas 9 satuan pendidikan kesetaraan paket b mata pelajaran PKN kompetensi dasar mendeskripsikan politik luar negeri dalam hubungan internasional di era global semester genap tahun ajaran 2019.

Adapun rumusan permasalahan dalam penelitian tindakan ini meliputi (1) bagaimana implementasi pemanfaatan materi perjanjian kerja sama sebagai media pembelajaran PKN untuk meningkatkan hasil belajar peserta didik? (2) berapakah persentase peningkatan hasil belajar peserta didik setelah implementasi pemanfaatan materi perjanjian kerja sama sebagai media pembelajaran PKN? Selanjutnya, tujuan penelitian ini antara lain (1) Mendeskripsikan implementasi pemanfaatan materi perjanjian kerja sama sebagai media pembelajaran PKN untuk meningkatkan hasil belajar peserta didik. (2) mengetahui 
persentase peningkatan hasil belajar sebelum dan sesudah implementasi pemanfaatan materi perjanjian kerja sama sebagai media pembelajaran PKN.

Manfaat penelitian ini yaitu (1) Hasil Penelitian ini dapat di gunakan sebagai masukan bagi guru atau tenaga kependidikan tentang implementasi pembelajaran inovatif. (2) Memberikan informasi bagi guru atau tenaga kependidikan dalam menyelenggarakan pembelajaran inovatif bermuatan karakter. (3) Dapat dijadikan sebagai pertimbangan bagi satuan PAUD dan Dikmas dalam mengatasi permasalahan rendahnya hasil belajar dan karakter peserta didik. (4) Diharapkan dapat meningkatkan mutu pembelajaran bagi satuan PAUD dan Dikmas.

Perjanjian kerja sama sebagai media pembelajaran PKN merupakan hasil modifikasi dari langkah-langkah materi perjanjian kerja sama internasional yang dipelajari pada kelas sembilan kompetensi dasar mendeskripsikan politik luar negeri dalam hubungan internasional di era global. Pembelajaran berpedoman pada beberapa teori strategi dan metode pembelajaran menurut beberapa ahli. Langkah-langkah perjanjian kerjasama internasional secara umum meliputi (1) penjajakan, (2) perundingan, (3) perumusan naskah, (4) penerimaan naskah perjanjian, (5) penandatanganan dan (6) pengesahan naskah perjanjian (Bowo, 2015).

Pemanfaatan materi perjanjian kerja sama sebagai media pembelajaran PKN merupakan salah satu cara dalam mengimplementasikan pembelajaran inovatif. Melalui pemanfaatan materi perjanjian kerja sama sebagai media pembelajaran, mampu mengatasi permasalahan pembelajaran khususnya pada mata pelajaran PKN kompetensi dasar mendeskripsikan politik luar negeri dalam hubungan internasional di era global, sehingga mampu mewujudkan tujuan yang diharapkan. Kata perjanjian dapat diartikan sebagai suatu peristiwa di mana seorang atau sekelompok orang saling berjanji untuk melaksanakan suatu hal. Kata kerjasama merupakan usaha yang dilakukan oleh beberapa orang atau kelompok agar tercapai tujuan yang diharapkan. Sedangkan media pembelajaran merupakan perantara untuk memudahkan proses interaksi antara pendidik dengan peserta didik dan sumber belajar pada suatu lingkungan belajar untuk memudahkan memahami materi. Berdasarkan pengertian tersebut maka dapat dirumuskan bahwa perjanjian kerja sama sebagai media pembelajaran adalah suatu perantara untuk memudahkan dalam memahami materi yang terdiri dari serangkaian kegiatan, dimana peserta didik bersama- 
sama melakukan kesepakatan bersama yang diikat dalam sebuah dokumen tertulis sehingga tujuan pembelajaran dapat tercapai.

Beberapa teori strategi pembelajaran yang menjadi landasan dalam pembelajaran ini meliputi (1) kolaboratif, (2) presentasi, (3) bermain peran dan (3) pemanfaatan teknologi informasi dan komunikasi. Sedangkan beberapa teori metode pembelajaran yang menjadi landasan dalam pembelajaran ini yaitu (1) Ceramah, (2) pembelajaran berbasis proyek, (3) pembelajaran kooperatif dan (4) pembelajaran berbasis teks. Materi beberapa langkah perjanjian internasional dan beberapa teori strategi dan metode pembelajaran bermuatan karakter tersebut, saya kolaborasi dan modifikasi sesuai kebutuhan. Hasilnya saya namakan pemanfaatan materi perjanjian kerja sama sebagai media pembelajaran. Pembelajaran tersebut saya implementasikan dalam mata pelajaran PKN kompetensi dasar politik luar negeri dalam hubungan internasional di era global.

Beberapa penelitian yang relevan terkait pembelajaran ini diantaranya, pertama hasil penelitian Nuryati dkk (2017) \& Bowo (2012) menunjukan bahwa pembelajaran berkelompok atau kooperatif mampu meningkatkan hasil belajar siswa. Selanjutnya Bowo (2015) mengungkapkan bahwa pembelajaran small group discussion dapat diterapkan dalam pembelajaran PKN. Berpedoman pada hasil penelitian tersebut dapat disimpulkan bahwa penerapan pembelajaran PKN melalui kelompok kecil mampu meningkatkan hasil belajar peserta didik. Tahapan pembelajaran PKN melalui pemanfaatan materi perjanjian kerjasama dilakukan melalui kelompok kecil.

Tahapan perincian proses implementasi pemanfaatan materi perjanjian kerjasama sebagai media pembelajaran yaitu terlebih dahulu tutor melakukan identifikasi permasalahan pembelajaran PKN pada kompetensi dasar mendeskripsikan politik luar negeri bebas aktif dalam hubungan internasional di era global. Beberapa permasalahan yang di hadapi oleh peserta didik pada kompetensi dasar tersebut yaitu peserta didik belum memahami alur atau proses negara dalam melakukan hubungan internasional di era global serta prinsip-prinsip apa yang harus di jalankan. Setelah menemukan permasalahan, tutor membuat rencana pelaksanaan pembelajaran meliputi identitas rencana pelaksanaan pembelajaran, standar kompetensi, kompetensi dasar, tujuan, indikator, prosedur pembelajaran, media pembelajaran, bahan ajar, penilaian dan lain-lain yang berkaitan tentang proses pembelajaran. Tahapan selanjutnya adalah pelaksanaan pembelajaran melalui pemanfaatan materi perjanjian kerja sama sebagai media pembelajaran antara lain 
identifikasi materi hubungan internasional melalui perjanjian kerja sama internasional, perundingan, perumusan naskah dan pengesahan yang memuat nilai-nilai karakter gotong royong, mandiri, dan nasionalis. Pada tahapan pelaksanaan tutor sebagai fasilitator. Selama pelaksanaan pembelajaran tutor mengamati kegiatan peserta didik untuk melakukan penilaian afektif dan psikomotorik. Setelah selesai pelaksanaan perjanjian kerja sama dilakukan penilaian kognitif berupa test pilihan ganda dan uraian. Selanjutnya melakukan evaluasi dan dampak nya. Tahapan perincian kegiatan proses implementasi pemanfaatan materi perjanjian kerjasama sebagai media pembelajaran PKN sebagaimana dipaparkan dalam gambar 1 berikut ini.

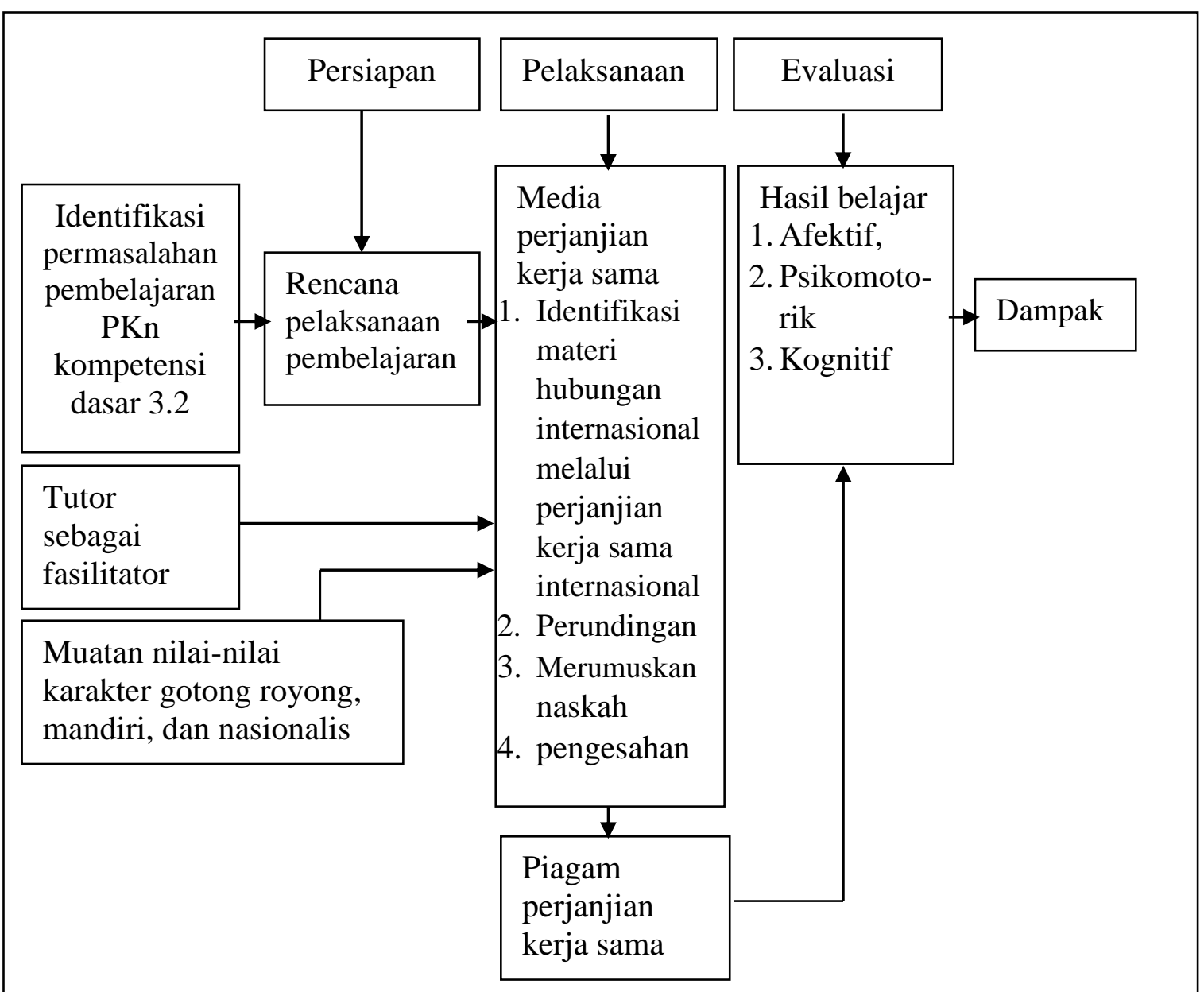

Gambar 1. Tahapan Perincian Kegiatan Proses Implementasi Pemanfaatan Materi Perjanjian Kerjasama sebagai Media Pembelajaran PKN

\section{METODE PENELITIAN}

Penelitian ini merupakan penelitian tindakan kelas. Tempat penelitian ini adalah di Homeschooling Anak Pelangi Yogyakarta pada kelas satuan pendidikan kesetaraan paket B tahun 2019. Subjek penelitian ini adalah guru PKN, peneliti, dan peserta didik kelas 9. 
Teknik pengumpulan data yang digunakan dalam penelitian ini adalah dengan teknik observasi, wawancara dan dokumentasi. Berpedoman pada Miles dan Huberman (1992) analisis data dalam penelitian ini menggunakan teknik analisis data model alir. Adapun langkah-langkah teknik analisis data sebagai berikut:

1. Pengumpulan data, yaitu mengumpulkan data di lokasi penelitian dengan melakukan observasi, wawancara, dan dokumentasi dengan menentukan strategi pengumpulan data yang dipandang tepat dan untuk menentukan fokus serta pendalaman data pada proses pengumpulan data berikutnya.

2. Reduksi data, yaitu sebagai proses pemilihan, pemfokusan, pengabstrakan, transformasi data kasar yang ada di lapangan langsung, dan diteruskan pada waktu pengumpulan data, dengan demikian reduksi data dimulai sejak peneliti mulai memfokuskan wilayah penelitian.

3. Penyajian data, yaitu rakitan organisasi informasi yang memungkinkan adanya penarikan kesimpulan saat penelitian dilakukan. Dalam penyajian data diperoleh berbagai jenis metrik gambar, jaringan kerja, keterkaitan kegiatan atau tabel.

4. Penarikan kesimpulan, yaitu dalam pengumpulan data, peneliti harus mengerti dan tanggap terhadap sesuatu yang diteliti langsung di lapangan dengan menyusun pola-pola pengarahan dan sebab-akibat.

Berpedoman pada Arikunto (2010), prosedur penelitian ini meliputi empat tahapan yang harus dilalui, yaitu (1) perencanaan (2) pelaksanaan, (3) pengamatan, (4) refleksi. Diharapkan melalui pemanfaatan materi perjanjian kerjasama sebagai media pembelajaran PKN dapat meningkatkan hasil belajar peserta didik SMP kelas 9.

\section{HASIL DAN PEMBAHASAN}

\section{A. Implementasi Pemanfaatan Materi Perjanjian Kerjasama sebagai Media Pembelajaran PKN}

Berpedoman pada permasalahan yang ada sebagaimana dipaparkan pada bagian pendahuluan, selanjutnya tutor membuat rencana pelaksanaan pembelajaran implementasi pemanfaatan materi perjanjian kerjasama sebagai media pembelajaran. Rencana pelakasanaan pembelajaran dapat dilihat pada gambar 2 berikut. 


\section{LESSON PLAN}

\begin{tabular}{ll}
\hline Identitas Lesson Plan & \\
Nama Tutor & $:$ Mr Nasir \\
Mata Pelajaran & $:$ Pendidikan Kewarganegaraan \\
Kelas/Semester & $: I X / 2$ \\
Jumlah Pertemuan/waktu & $: 2$ kali Pertemuan (Siklus I \& II)
\end{tabular}

\begin{tabular}{|ll}
\hline Judul Lesson Plan & $:$ :Politik Luar Negeri dalam Hubungan Internasional" \\
Standar Kompetensi & $: M e m a h a m i$ dampak globalisasi dalam kehidupan \\
& bermasyarakat, berbangsa dan bernegara \\
Kompetensi Dasar & $\begin{array}{l}\text { :Mendeskripsikan politik luar negeri dalam hubungan } \\
\text { internasional diera global }\end{array}$
\end{tabular}

Catatan: Rumusan Standar kompetensi dan kompetensi dasar mengacu pada standar isi kurikulum KTSP PKn

\section{Tujuan/Hasil Belajar}

Setelah membaca materi bab tentang usaha pembelaan negara dan mempelajarinya:

1. Peserta didik dapat menjelaskan arti politik luar negeri bebas aktif.

2. Peserta didik dapat menunjukkan dasar hukum politik luar negeri Indonesia bebas aktif.

3. Peserta didik dapat menyebutkan tujuan politik luar negeri RI.

4. Peserta didik dapat menjelaskan arti pentingnya hubungan internasional.

5. Peserta didik dapat menyebutkan tahapan-tahapan perjanjian internasional.

6. Peserta didik dapat menjelaskan peranan Indonesia dalam perdamaian dunia

\section{Indikator Tujuan/Hasil Belajar}

1. Peserta Didik mampu menjelaskan hakekat politik luar negeri bebas aktif.

2. Peserta Didik mampu menguraikan landasan hukum politik luar negeri Indonesia.

3. Peserta Didik mampu menyebutkan tujuan politik luar negeri.

4. Peserta didik mampu menjelaskan pentingnya hubungan dan tahapan perjanjian internasional.

5. Peserta Didik mampu menjelaskan peranan Indonesia dalam hubungan internasional.

\section{Peta Konsep}

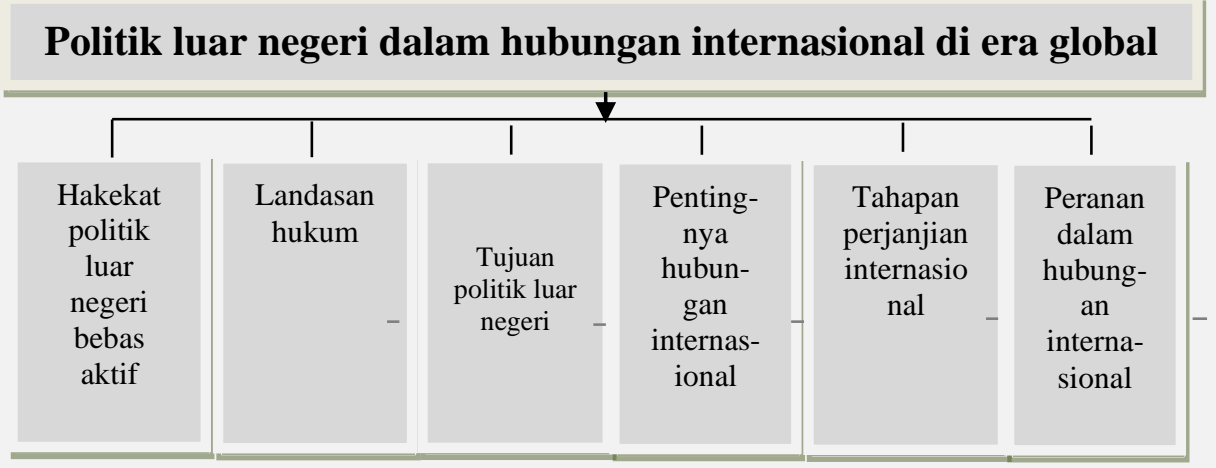

Sub Topik Materi Pembelajaran: 1. Arti politik luar negeri bebas aktif

2. Dasar hukum politik luar negeri Indonesia bebas aktif

3. Tujuan politik luar negeri RI

4. Pentingnya hubungan internasional 


\begin{tabular}{|c|c|}
\hline \multicolumn{2}{|c|}{$\begin{array}{l}\text { 5. Tahapan perjanjian internasional } \\
\text { 6. Peranan Indonesia dalam hubungan internasional } \\
\text { Metode Pembelajaran: ceramah, pemb berbasis proyek, berbasis teks, dan kooperatif. } \\
\text { Strategi Pembelajaran: kolaboratif, presentasi, bermain peran, dan pemanfaatan TIK }\end{array}$} \\
\hline \multicolumn{2}{|l|}{ AKTIVITAS } \\
\hline \multicolumn{2}{|l|}{ Zona Alfa } \\
\hline Kegiatan Pembelajaran Tutor dan Peserta Didik & Sikap/Nilai Karakter \\
\hline $\begin{array}{l}\text { A. Pendahuluan (7 menit) } \\
\text { 1. Salam pembuka dan berdoa } \\
\text { Peserta didik dan tutor bersama-sama berdoa sesuai } \\
\text { agamanya masing-masing } \\
\text { 2. Ice breaking, siswa mengikuti intruksi tutor. Tutor } \\
\text { memberikan permainan edukatif "tepuk tunggal dan } \\
\text { ganda (test konsentrasi)". } \\
\text { 3. Tutor melakukan presensi dan menanyakan keadaan } \\
\text { siswa } \\
\text { 4. Apersepi, tutor memberikan motivasi kepada peserta } \\
\text { didik melalui kata-kata bijak para pahlawan. } \\
\text { 5. Peserta didik bersama tutor melakukan display dan } \\
\text { penyusunan tata letak meja dan kursi ruang kelas. } \\
\text { tata letak meja dan kursi di buat latter U. hal ini } \\
\text { dimaksudkan agar antar peserta didik dapat lebih } \\
\text { mudah dalam berinteraksi dan komunikasi. }\end{array}$ & $\begin{array}{lc}\text { 1. } & \text { Religius-taqwa } \\
\text { 2. } & \text { Gotong royong } \\
\text { (Kerjasama). Mandiri } \\
\text { (disiplin). } \\
\text { 3. } \\
\text { Empati, Mandiri } \\
\text { (disiplin). } \\
\text { Nasionalis } \\
\text { (Semangat kebangsaan). } \\
\text { Motivasi } \\
\text { 5. Gotong royong } \\
\text { (Kerjasama). Mandiri ( } \\
\text { kerapian). }\end{array}$ \\
\hline $\begin{array}{l}\text { B. Inti (46 menit) } \\
\text { 1. Peserta didik mendengarkan penjelasan dari tutor } \\
\text { terkait materi secara umum tentang politik luar } \\
\text { negeri dalam hubungan internasional di era global. } \\
\text { Meliputi (a). arti politik bebas aktif, (b) dasar hukum } \\
\text { politik luar negeri, (c) tujuan politi luar negeri, (d) } \\
\text { pentingnya hubungan internasional, (e) tahapan } \\
\text { perjanjian internasional, dan (f) peranan indonesia } \\
\text { dalam perdamaian dunia. Dalam mejelaskan materi, } \\
\text { agar mudah di pahami dan interaktif, terlebih dahulu } \\
\text { tutor memberi pertanyaan kepada peserta didik } \\
\text { terkait materi dengan menggunakan gambar. } \\
\text { (eksplorasi) } \\
\text { 2. Peserta didik mendengarkan penjelasan tutor tentang } \\
\text { penyampaian langkah-langkah pembelajaran yang di } \\
\text { lakukan. (eksplorasi) }\end{array}$ & 1. Mandiri (Pembelajar) \\
\hline $\begin{array}{l}\text { 3. Peserta didik melakukan perundingan terkait } \\
\text { permasalahan internasional serta solusi yang harus } \\
\text { dilakukan }\end{array}$ & $\begin{array}{l}\text { 3. Gotong Royong } \\
\text { (solidaritas). Nasionalis } \\
\text { (menghargai kebhinekaan). } \\
\text { Mandiri (disiplin). } \\
\text { 4. Mandiri (kerja keras, }\end{array}$ \\
\hline
\end{tabular}


4. Masing-masing peserta didik menuliskan naskah hasil kesepakatan bersama terkait solusi permasalahan yang telah di sepakati. (eksplorasi)

5. Masing-masing peserta didik membaca kembali isi naskah perjanjian, menyepakati bersama rumusan naskah perjanjian. Selanjutnya masing-masing menerima naskah perjanjian dan menandatangani naskah perjanjian serta ratifikasi kemudian di terapkan bersama. (eksplorasi, elaburasi, konfirmasi)

6. Tutor memberi penguatan materi dan memberikan kesempatan kepada peserta didik untuk bertanya apabila ada materi yang belum di pahami. (eksplorasi, elaburasi, konfirmasi) disiplin, kreatif, pembelajar). Nasionalis (cinta tanah air)

5. Gotong Royong

(kerjasama, solidaritas, saling menolong, kekeluargaan). Mandiri (kerjakeras, disiplin, berani, kreatif, pembelajar).

Naionalis (cinta tanah air, semangat kebangsaan, menghargai kebhinekaan).

\section{Gotong Royong}

(kerjasama, solidaritas, saling menolong, kekeluargaan). Mandiri (kerjakeras, disiplin, berani, kreatif, pembelajar).

Nasionalis (cinta tanah air, semangat kebangsaan, menghargai perbedaan).

\section{Penutup (7 menit)}

1. Peserta didik dan tutor bersama-sama menyimpulkan materi yang dipelajari. (konfirmasi)

2. Tindak lanjut pertemuan berikutnya, tutor memberi tugas kepada peserta didik yaitu berupa pertanyaan essay. Sumber belajar melalui internet atau buku. Selanjutnya menginstruksikan kepada peserta didik bahwa pertemuan yang akan datang adalah ulangan

3. Salam penutup dan berdoa

\section{Sumber Belajar}

1. Buku ajar/ e-book, dan modul PKN kelas IX SMP Penulis Sugeng Priyanto, dkk. Bukubuku terkait materi yang dipelajari

2. Website berbagai sumber terkait materi yang dipelajari (internet)

3. Artikel atau majalah/surat kabar kedaulatan rakyat dan tribun jogja

4. LKS pembelajaran PKN dan Lingkungan

\section{Media Pembelajaran}




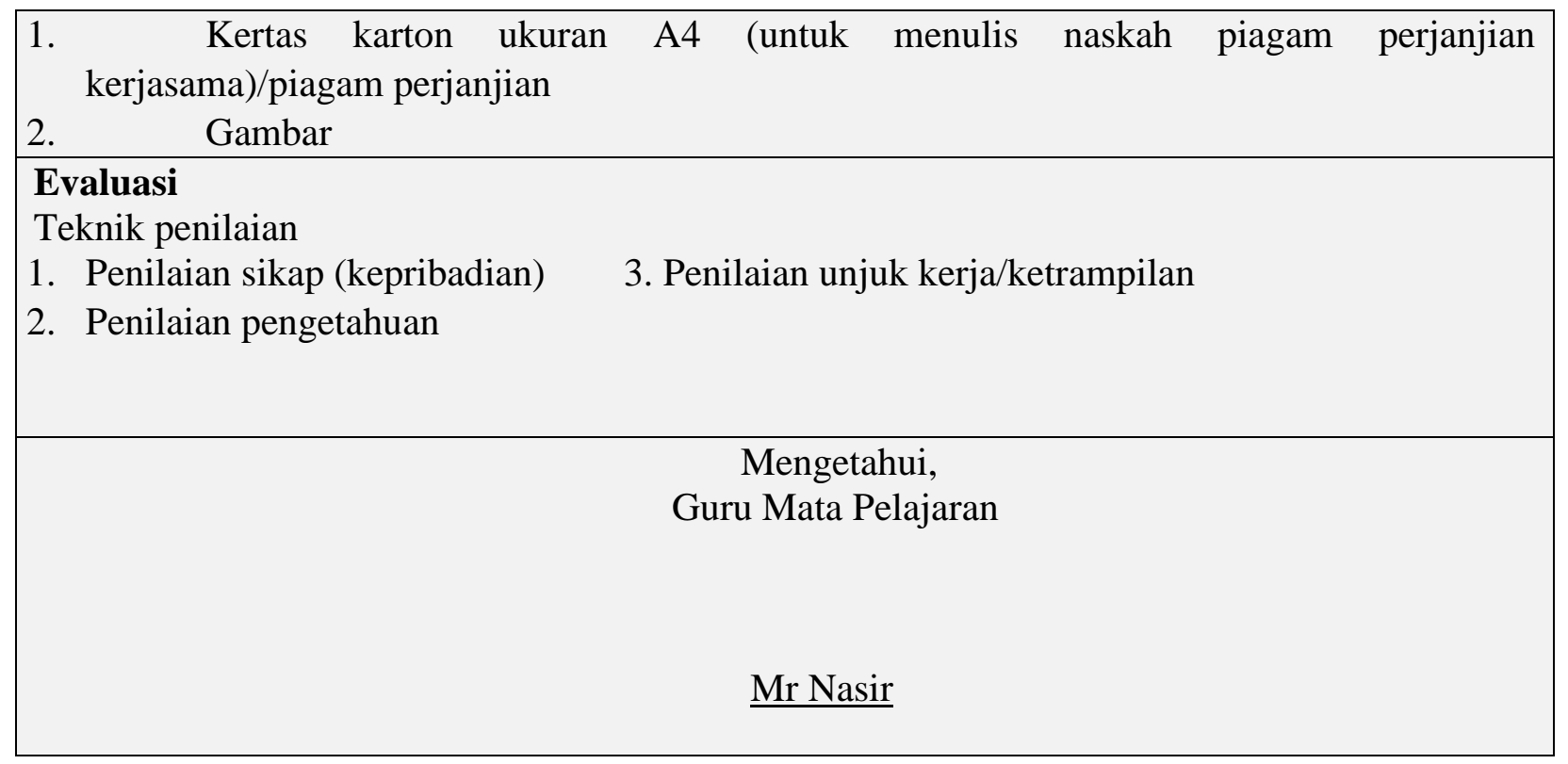

\section{Gambar 2. RPP Implementasi Materi Perjanjian Kerjasama Sebagai Media Pembelajaran PKN}

Capaian indikator keberhasilan implementasi pemanfaatan materi perjanjian kerjasama sebagai media pembelajaran PKN yaitu peningkatan hasil belajar peserta didik. Aspek yang di nilai meliputi aspek afektif untuk mengetahui peningkatan sikap, psikomotorik untuk mengetahui ketrampilan peserta didik dan kognitif untuk mengetahui peningkatan kemampuan pengetahuan peserta didik selama pembelajaran. Ke tiga penilaian tersebut selanjutnya didapat nilai hasil belajar peserta didik.

1. Penilaian Afektif

Terdapat peningkatan hasil belajar dan karakter melalui implementasi pemanfaatan materi perjanjian kerja sama sebagai media pembelajaran PKN. Peningkatan ini dapat dilihat dari nilai afektif peserta didik. Penerapan sikap yang meningkat antara lain (a) mandiri meliputi kerja keras, disiplin, berani, kreatif, dan pembelajar, (b) gotong royong, meliputi kerjasama, solidaritas, saling menolong, dan kekeluargaan, (c) nasionalis, meliputi cinta tanah air, semangat kebangsaan, dan menghargai perbedaan. Skor nilai afektif yang dicapai sebelum dan sesudah implementasi pemanfaatan materi perjanjian kerjasama sebagai media pembelajaran PKN dapat dilihat pada tabel 1 berikut.

Tabel 1. Nilai Afektif Sebelum dan Sesudah Implementasi Pemanfaatan Materi Perjanjian Kerjasama sebagai Media Pembelajaran PKN

\begin{tabular}{|c|c|c|}
\hline $\begin{array}{c}\text { Nilai Rata-Rata Sebelum } \\
\text { Implementasi }\end{array}$ & $\begin{array}{c}\text { Nilai Rata-Rata Sesudah } \\
\text { Implementasi Siklus I }\end{array}$ & Nilai Rata-Rata \\
\hline 58,3 & 80,4 & 89,5 \\
\hline
\end{tabular}


Nilai rata-rata sebelum implementasi pemanfaatan materi perjanjian kerja sama sebagai media pembelajaran adalah 58,3. Sesudah implementasi pemanfaatan materi perjanjian kerja sama sebagai media pembelajaran, nilai rata-rata afektif nya pada siklus I adalah 80,4 sedangkan pada siklus ke II meningkat menjadi 89,5.

2. Penilaian Psikomotorik

Terdapat peningkatan psikomotorik peserta didik melalui pemanfaatan materi perjanjian kerjasama sebagai media pembelajaran PKN. Peningkatan ini dapat dilihat dari nilai psikomotorik peserta didik selama proses pembelajaran berlangsung. Ketrampilan yang di nilai adalah diskusi dan presentasi atau cara penyampaian peserta didik dalam menjelaskan argumen. Skor nilai psikomotorik yang dicapai sebelum dan sesudah implementasi pemanfaatan materi perjanjian kerjasama sebagai media pembelajaran PKN dapat di lihat pada tabel 2 berikut.

Tabel 2. Nilai Psikomotorik Sebelum dan Sesudah pemanfaatan Materi Perjanjian Kerjasama Sebagai Media Pembelajaran PKN

\begin{tabular}{|c|c|c|}
\hline $\begin{array}{c}\text { Nilai Rata-Rata Sebelum } \\
\text { Implementasi }\end{array}$ & $\begin{array}{c}\text { Nilai Rata-Rata Sesudah } \\
\text { Implementasi Siklus I }\end{array}$ & $\begin{array}{c}\text { Nilai Rata-Rata Sesudah } \\
\text { Implementasi II }\end{array}$ \\
\hline 59 & 84 & 93,4 \\
\hline
\end{tabular}

Nilai rata-rata sebelum implementasi pemanfaatan materi perjanjian kerjasama sebagai media pembelajaran PKN adalah 59. Sesudah implementasi nilai rata-rata psikomotorik nya pada siklus I meningkat menjadi 84 . Sedangkan pada siklus ke II meningkat menjadi 93,4 .

\section{Penilaian Kognitif}

Terdapat peningkatan pengetahuan peserta didik melalui implementasi pemanfaatan materi perjanjian kerjasama sebagai media pembelajaran PKN. Peningkatan ini dapat dilihat dari nilai test tertulis individu berupa pilihan ganda, tugas kelompok yaitu membuat laporan tertulis selama proses pembelajaran dan tugas individu (take home). Skor nilai kognitif yang dicapai sebelum dan sesudah implementasi pemanfaatan materi perjanjian kerjasama sebagai media pembelajaran PKN dapat di lihat pada tabel 3 berikut.

Tabel 3. Nilai Kognitif Sebelum dan Sesudah Implementasi Pemanfaatan Materi Perjanjian Kerjasama Sebagai Media Pembelajaran PKN

\begin{tabular}{|c|c|c|}
\hline $\begin{array}{c}\text { Nilai Rata-Rata Sebelum } \\
\text { Implementasi }\end{array}$ & $\begin{array}{c}\text { Nilai Rata-Rata Sesudah } \\
\text { Implementasi Siklus I }\end{array}$ & $\begin{array}{c}\text { Nilai Rata-Rata Sesudah } \\
\text { Implementasi Siklus II }\end{array}$ \\
\hline 56 & 88 & 95,3 \\
\hline
\end{tabular}

Nilai rata-rata sebelum implementasi pemanfaatan materi perjanjian kerjasama sebagai media pembelajaran PKN adalah 56. Sesudah implementasi pemanfaatan materi perjanjian 
kerjasama sebagai media pembelajaran PKN, nilai rata-rata kognitif nya pada siklus I adalah 88. Pada siklus II menjadi 95,3.

Selanjutnya, media pembelajaran dalam bentuk kertas karton ukuran A4 (untuk menulis naskah piagam perjanjian kerjasama)/piagam perjanjian. Adapun Media tersebut dapat dilihat sebagaimana gambar 3 berikut.

\section{PIAGAM PERJANJIAN KERJASAMA}

Dengan rahmat Tuhan Yang Maha Esa kami membuat kesepakatan dalam bentuk perjanjian kerjasama meliputi:

1. Bersama-sama berkomitmen mengatasi permasalahan Internasional antara lain:

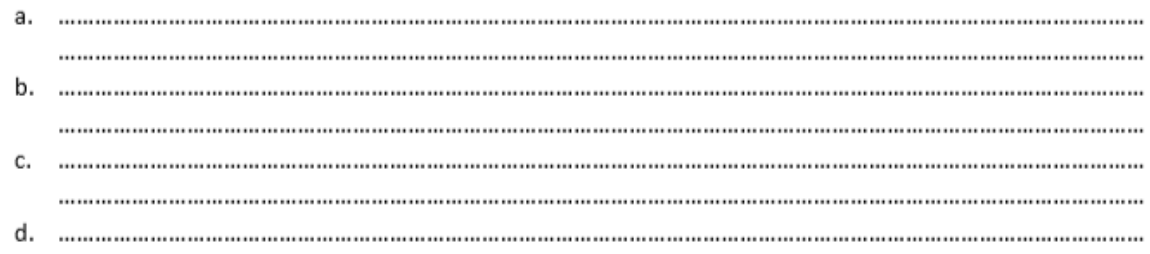

2. Adapun poin-poin penting materi politik luar negeri dalam hubungan internasional yaitu:

3. Kami berkomitmen untuk melaksanakan nilai-nilai karakter, meliput

Demikian Piagam Perjanjian Kerjasama yang kami sepakati.

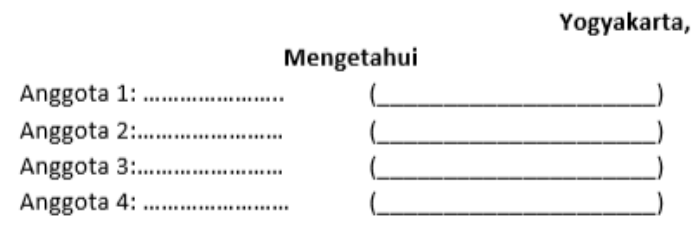

Gambar 3. Media Pembelajaran Perjanjian Kerjasama 
B. Presentase Peningkatan Hasil Belajar Pemanfaatan Materi Perjanjian Kerjasama sebagai Media Pembelajaran PKN

Berdasarkan tabel 1, 2 dan 3 sebagaimana di paparkan pada sub bab sebelumnya, maka dapat diketahui bahwa terdapat peningkatan hasil belajar sesudah implementasi pemanfaatan materi perjanjian kerjasama sebagai media pembelajaran PKN baik pada siklus I dam II. Peningkatan hasil belajar dapat diperoleh dengan mencari nilai rata-rata afektif, psikomotorik dan kognitif. Selanjutnya persentase total nilai rata-rata peningkatan hasil belajar peserta didik dapat dilihat pada tabel berikut.

Tabel 3. Persentase Total Nilai Rata-Rata Peningkatan Hasil Belajar Sebelum dan Sesudah Implementasi Pemanfaatan Materi Perjanjian Kerjasama Sebagai Media Pembelajaran PKN

\begin{tabular}{|c|c|c|}
\hline $\begin{array}{c}\text { Persentase Nilai Rata-Rata } \\
\text { Sebelum Implementasi }\end{array}$ & $\begin{array}{c}\text { Persentase Nilai Rata-Rata } \\
\text { Sesudah Implementasi Siklus I }\end{array}$ & $\begin{array}{c}\text { Persentase Nilai Rata-Rata } \\
\text { Sesudah Implementasi Siklus II }\end{array}$ \\
\hline $\begin{array}{c}\text { Total Nilai Rata-Rata 67,7 } \\
\text { Persentase 28\% }\end{array}$ & $\begin{array}{c}\text { Total Nilai Rata-Rata 84,1\% } \\
\text { Persentase 34\% }\end{array}$ & $\begin{array}{c}\text { Total Nilai Rata-Rata 92,7 } \\
\text { Persentase 38\% }\end{array}$ \\
\hline
\end{tabular}

Persentase total nilai rata-rata peningkatan hasil belajar sebelum dan sesudah implementasi pemanfaatan materi perjanjian kerjasama sebagai media pembelajaran PKN pada tabel di atas, dapat dibuat diagram sebagaimana gambar berikut.

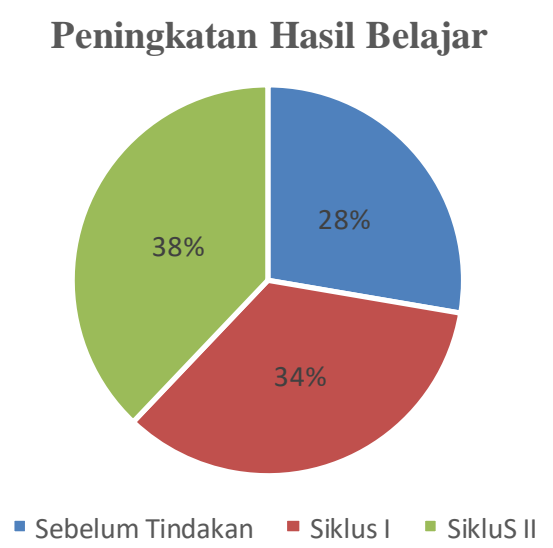

Gambar 4. Peningkatan Hasil Belajar Peserta Didik melalui Pemanfaatan Materi Perjanjian Kerja Sama sebagai Media Pembelajaran PKN

Berdasarkan tabel dan gambar di atas jumlah total nilai rata-rata hasil belajar sebelum tindakan adalah $28 \%$. Setelah tindakan pada siklus pertama meningkat menjadi $34 \%$. Pada siklus ke II meningkat menjadi $38 \%$.

Dampak implementasi pemanfaatan materi perjanjian kerjasama sebagai media pembelajaran PKN dapat meningkatkan hasil belajar peserta didik. Dampak implementasi dapat di lihat dari hasil belajar dan pengamatan sehari-hari meliputi pengamatan di lingkungan sekolah, keluarga dan masyarakat. Dapat di buktikan melalui testimoni pihak 
keluarga, sekolah dan masyarakat. Ada keinginan tutor lain untuk menerapkan, khususnya pada mata pelajaran PKN dan umumnya pada mata pelajaran yang lain.

Kendala-kendala yang di hadapi serta solusi yang dilakukan pada saat implementasi pemanfaatan materi perjanjian kerjasama sebagai media pembelajaran PKN sebagaimana di paparkan dalam gambar di bawah ini.

\begin{tabular}{|c|c|c|}
\hline Kendala & & Solusi \\
\hline $\begin{array}{l}\text { 1. Pada tahap awal sebagian peserta } \\
\text { didik belum begitu memahami } \\
\text { dan masih bingung tahapan } \\
\text { peman-faatan materi perjanjian } \\
\text { kerja sama sebagai Media Pem- } \\
\text { belajaran PKN. }\end{array}$ & & $\begin{array}{l}\text { Tutor mengulangi penjelasan tahapan nya. } \\
\text { Tutor melakukan penyederhanaan cara } \\
\text { penyampaian peman-faatan materi } \\
\text { perjanjian kerja sama sebagai Media } \\
\text { Pembelajaran PKN, agar mudah dipahami } \\
\text { peserta didik. }\end{array}$ \\
\hline $\begin{array}{l}\text { 2. Pemanfaatan waktu proses } \\
\text { pembelajaran yang masih kurang } \\
\text { disiplin. }\end{array}$ & & $\begin{array}{l}\text { Tutor memberikan waktu untuk } \\
\text { menyelesaikan tahapan pembelajaran } \\
\text { kepada peserta didik agar tepat waktu, dan } \\
\text { menyederhanakan materi dengan tidak } \\
\text { mengurangi esensi dari materi yang sudah di } \\
\text { rumuskan dalam standar isi. }\end{array}$ \\
\hline
\end{tabular}

Gambar 5. Kendala dan Solusi Implementasi Pemanfaatan Materi Perjanjian Kerja Sama sebagai Media Pembelajaran PKN

Berkaitan dengan solusi dalam mengatasi kendala kegiatan pembelajaran, ada apresiasi dari pihak pengelola ketika tutor mampu mengatasi berbagai kendala khususnya saat pembelajaran berupa intensif atau penghargaan. Selain itu, ada upaya sekolah untuk membangun kemitraan dengan pihak lain. Kegiatan yang sudah terealisasikan misalnya dengan Dinas Pendidikan Kota memfasilitasi bimbingan teknis terkait pengelolaan pendidikan, pembelajaran dan keterlibatan masyarakat untuk mengatasi berbagai permasalahan atau kendala pendidikan dan pembelajaran. selain itu bekerja sama dengan penerbit buku erlangga dan lain-lain. Beberapa faktor pendukung keberhasilan dalam penerapan pembelajaran ini antara lain:

1. Faktor internal, meliputi: (a) sumber daya manusia yaitu ada dukungan dan kerjasama baik dengan lembaga, tutor kolegial yang lain, peserta didik, dan kemampuan tutor dalam mengelola pembelajaran, (b) sarana dan prasarana pembelajaran yang cukup antara lain: ruang kelas, alat dan media pembelajaran, sumber referensi belajar dan fasilitas yang lainnya, (c) suasana sekolah dan kelas yang kondusif, aman, tentram dan damai. 
2. Faktor eksternal yaitu dukungan dan kerjasama dengan orang tua peserta didik, masyarakat sekitar, Dinas Pendidikan Kota dan instansi pendidikan lain yang terkait.

\section{SIMPULAN}

Beberapa kesimpulan karya nyata ini sebagaimana di paparkan dalam uraian berikut:

1. Tahapan implementasi pemanfaatan materi perjanjian kerjasama sebagai media pembelajaran di bagi menjadi tiga tahap. Tahap pertama yaitu perencanaan, tutor membuat rencana pelaksanaan pembelajaran. Tahap kedua yaitu tahap pelaksanaan, meliputi identifikasi materi hubungan internasional melalui perjanjian kerja sama internasional, perundingan, perumusan naskah dan pengesahan sehingga disepakati isi piagam perjanjian kerja sama. Tahap ketiga yaitu evaluasi, untuk mengetahui hasil belajar melalui penilaian afektif, psikomotorik dan kognitif. Selanjutnya diperoleh dampak hasil pembelajaran.

2. Persentase peningkatan hasil belajar melalui pemanfaatan materi perjanjian kerjasama sebagai media pembelajaran yaitu jumlah total nilai rata-rata hasil belajar sebelum tindakan adalah $28 \%$. Setelah tindakan pada siklus pertama meningkat menjadi $34 \%$. Pada siklus ke II meningkat menjadi $38 \%$.

\section{SARAN}

Implementasi pemanfaatan materi perjanjian kerja sama dapat di jadikan referensi dalam pembelajaran di satuan pendidikan kesetaraan khususnya dalam meningkatkan hasil belajar. Dinas pendidikan dapat mensosialisasikan tentang berbagai strategi, metode maupun media yang dapat meningkatkan hasil belajar dan karakter peserta didik, salah satunya adalah materi perjanjian kerja sama sebagai media pembelajaran.

Tutor dapat terus menerus melakukan ujicoba pengembangan pembelajaran inovatif untuk mendapatkan hasil yang maksimal. Dapat berupa pengembangan materi perjanjian kerja sama sebagai media pembelajaran yang dapat diterapkan diberbagai mata pelajaran. materi perjanjian kerja sama sebagai media pembelajaran dapat dikolaburasikan dengan beberapa metode dan strategi pembelajaran yang sudah ada. Selanjutnya di peroleh berbagai pengembangan pembelajaran pemanfaatan materi perjanjian kerja sama sebagai media pembelajaran yang inovatif. Harapan selanjutnya pemanfaatan materi perjanjian kerja sama sebagai media pembelajaran dapat dikembangkan menjadi program nasional 
dan di sosialisasikan serta dipublikasikan dalam bentuk buku atau jurnal, sehingga dapat bermanfaat bagi pembaca pada umumnya dan praktisi pendidikan khususnya.

\section{DAFTAR PUSTAKA}

Arikunto, S. (2010). Prosedur Penelitian: Suatu Pendekatan Praktik. Jakarta: Rineka Cipta.

Bowo, A. N. A. (2012). Strategi Index Card Match untuk Peningkatan Pemahaman Siswa SMK Mata Pelajaran PKN. Academy of Education Journal, 3(1).

Bowo, A. N. A. (2015). Cerita Cinta Belajar Mengajar. Deepublish.

Bowo, A. N. A. (2015). Pengembangan Pengelolaan Pembelajaran Ekonomi Berbasis Lingkungan dengan Strategi Small Graup Discussion di SMA Muhammadiyah 1 Surakarta. Academy of Education Journal, 6(1).

Nuryati, N., \& Bowo, A. N. A. (2015). Pengembangan Model Pembelajaran PPKN Quantum Teaching Berbasis Lingkungan melalui Cooperative Learning di SMA Negeri Kota Yogyakarta. Academy of Education Journal, 6(2).

Nuryati, N., Budiutomo, T. W., \& Bowo, A. N. A. (2017). Pengembangan Model Pembelajaran PPKN Anti Korupsi Berbasis Lingkungan melalui Cooperative Learning di SMA/SMK Swasta Kulon Progo Yogyakarta. Academy of Education Journal, 8(1), 27-49.

Miles, M. B. \& Huberman, M. (1992). Analisis Data Kualitatif. Jakarta: Penerbit Universitas Indonesia. 